\title{
MENGENAL TRADISI BARAPAN KEBO DI KABUPATEN SUMBAWA
}

\author{
Ranis Oktaviani \\ Mahasiswa Pascasarjana UIN Mataram
}

\begin{abstract}
Abstrak. Barapan kebo atau karapan kerbau merupakan permainan rakyat yang ada di Pulau Sumbawa, tepatnya di Kabupaten Sumbawa, Nusa Tenggara Barat. Barapan kebo ini merupakan suatu tradisi masyarakat agraris Sumbawa termasuk Sumbawa Barat yang hingga kini masih hidup di "Tanah Samawa" (sebutan lain bagi Kabupaten Sumbawa dan Sumbawa Barat). Tradisi ini digelar oleh masyarakat Suku Samawa setiap menjelang musim tanam tiba.Konon ceritanya, barapan kebo merupakan acara selamatan yang muncul dari tradisi bertani masyarakat "Tanah Samawa". Berangkat dari keinginan untuk menjadikan tanah yang mestinya siap ditanami padi sebanyak tiga kali. Dikarenakan jenis tanah di Pulau Sumbawa yang umumnya adalah tanah liat, maka barapan kebo diselenggarakan dengan tujuan untuk membantu petani dalam membajak sawah agar tanah yang akan ditanami dapat teroptimalkan dengan baik.
\end{abstract}

\section{Kata Kunci: Tradisi, Barapan Kebo}

\section{PENDAHULUAN}

Pulau Sumbawa adalah sebuah pulau yang terletak di provinsi Nusa Tenggara Barat, Indonesia. Pulau ini dibatasi oleh Selat Alas di sebelah barat (memisahkan dengan Pulau Lombok), Selat Sape di sebelah timur (memisahkan dengan Pulau Komodo), Samudra Hindia di sebelah selatan, serta Laut Flores di sebelah utara. Kota terbesarnya adalah Bima, yang berada di bagian timur pulau ini.

Kekayaan budaya yang dimiliki masing-masing daerah khususnya daerah Sumbawa, harus bisa di jaga serta dilestarikan, dikarenakan budaya tersebut merupakan sebuah warisan yang nantinya akan diwariskan kepada generasi penerus bangsa ini di masa yang akan datang. Dengan tetap bercermin terhadap sejarah leluhur agar mampu menjaga serta tetap eksis ditengah perkembangan jaman dewasa kini.

Suku Sumbawa tersebar di dua kabupaten, yaitu kabupaten Sumbawa dan kabupaten Sumbawa Barat yang meliputi kecamatan Empang di ujung timur hingga kecamatan Taliwang dan Sekongkang yang berada di ujung barat dan selatan pulau, termasuk 38 pulau kecil di sekitarnya. Masyarakat suku Sumbawa pada umumnya hidup pada bidang pertanian. Mereka menanam padi di sawah dengan menggunakan peralatan tradisional berupa cangkul atau bingkung, rengala, dan kareng sebagai peralatan bajak dengan memanfaatkan hewan peliharaan seperti sapi dan kerbau. Dalam menggarap ladang mereka masih menggunakan cara tradisional, yaitu dengan membakar lahan pertanian agar mempermudah proses penanaman beberapa jenis tanaman pangan.Beragam tradisi tumbuh dan berkembang dalam kehidupan masyarakatnya mulai dari tradisi perkawinan yang unik, bahasa lisan (rabalas lawas dan sakeco) yang terdengar sangat asing tetapi syarat makna dan acara hiburan yang menguji adrenalin (barapan kebo, barempuk dan main jaran,dll).

Adat istiadat dan budaya merupakan ciri khas suatu suku, Indonesia merupakan bangsa yang terkenal karena kaya akan adat istiadat yang berbeda pada tiap-tiap daerahnya. Barapan kebo atau karapan kerbau merupakan permainan rakyat yang ada di Pulau Sumbawa, tepatnya di Kabupaten Sumbawa, Nusa Tenggara Barat. Barapan kebo ini merupakan suatu tradisi masyarakat agraris Sumbawa termasuk Sumbawa Barat yang hingga kini masih hidup di "Tanah Samawa" (sebutan lain bagi Kabupaten Sumbawa dan Sumbawa Barat).

Budaya merupakan keseluruhan kompleks yang meliputi pengetahuan, kepercayaan, kesenian, moral, keilmuan, hukum, adat istiadat, dan 
kemampuan yang lain serta kebiasaan yang didapat oleh manusia sebagai anggota masyarakat. Kebudayaan adalah semua hasil karya, rasa dan cipta masyarakat. Setiap daerah memiliki ciri khas kebudayaannya masingmasing,termasuk masyarakat Sumbawa khususnya di bagian Sumbawa besar. Barapan kebo ini di jadikan sebagai ajang tempat mengadu ilmu antara joki, dan sandro yang menjaga sakak (garis finish). Sandro dalam bahasa sumbawa artinya Dukun, konon katanya, pada jaman dahulu barapan kebo menjadi ajang pertarungan ilmu para sandro, biasanya para sandro akan berdiri disekitar sakak/garis finish kemudian mengganggu kerbau yang sedang berlomba, misalnya dengan membuatnya terjatuh atau berbelok arah, hanya saja sang joki dan kerbau yang diganggu pun memiliki sandro pula, sehingga disitulah terjadi perang ilmu. Namun dimasa sekarang, dalam event barapan kebo sandro sudah tidak dipakai lagi. Bukan hadiah yang menjadi fokus utama dari event barapan kebo ini, karena memang hadiahnya tidaklah banyak, bahkan biaya yang harus dikeluarkan oleh pemilik kerbau jauh lebih banyak dari hadiah yang disediakan oleh panitia, akan tetapi bagi pemilik kerbau, perlombaan ini merupakan sebuah pertarungan prestise dan martabat, imbas lainnya adalah pada harga kerbau yang melonjak jika menjadi juara, bahkan katanya sepasang kerbau pemenang bisa dihargai hingga ratusan juta rupiah.Sejalan dengan perkembangan dunia pariwisata saat ini, barapan kebo kini dijadikan suguhan yang menarik untuk disaksikan bagi para wisatawan yang berkunjung ke Sumbawa, dan juga barapan kebo ini adalah merupakan bagian dari aset budaya yang harus dijaga kelestariannya. Bahkan beberapa hotel di Sumbawa menjual permainan rakyat ini sebagai paket wisata bagi para tourist.

\section{HASIL DAN PEMBAHASAN}

Barapan kebo atau karapan kerbau merupakan permainan rakyat yang ada di Pulau Sumbawa, tepatnya di Kabupaten Sumbawa, Nusa Tenggara Barat. Barapan kebo ini merupakan suatu tradisi masyarakat agraris Sumbawa termasuk Sumbawa Barat yang hingga kini masih hidup di "Tanah Samawa" (sebutan lain bagi Kabupaten Sumbawa dan Sumbawa Barat).

Konon ceritanya, barapan kebo merupakan acara selamatan yang muncul dari tradisi bertani masyarakat "Tanah Samawa". Berangkat dari keinginan untuk menjadikan tanah yang mestinya siap ditanami padi sebanyak tiga kali. Dikarenakan jenis tanah di Pulau Sumbawa yang umumnya adalah tanah liat, maka barapan kebo diselenggarakan dengan tujuan untuk membantu petani dalam membajak sawah agar tanah yang akan ditanami dapat teroptimalkan dengan baik. Seiring dengan berjalannya waktu, tradisi barapan kebo terus berkembang sampai sekarang, bahkan event budaya khas Sumbawa ini dilaksanakan setiap tahun, baik untuk kepentingan amal (menghimpun dana bagi pembangunan masjid, musholla, dan lain-lain), maupun dipertandingkan dengan hadiah berupa piala, kain sarung, kain bakal baju (batik), dan televisi yang disediakan bagi para pemenangnya. Hampir setiap desa menyelenggarakan barapan, hingga dari pihak panitia sendiri harus mengundang peserta dari luar Kabupaten Sumbawa untuk menyemarakkan acara.Ketika tradisi Barapan Kebo ini berlangsung, masyarakat Sumbawa dan sekitarnya berbondong-bondong menyaksikan jalannya perlombaan. Ditambah lagi area persawahan yang berlumpur terkadang menjadikan wajah para joki terlihat kotor karena terkena cipratan lumpur, namun inilah yang mengundang gelak tawa bagi para penonton Barapan Kebo.Memang kelihatannya sederhana dan mudah, namun ada tantangan tersendiri ketika menjadi joki Barapan Kebo tersebut. Menjaga kecepatan dan menyeimbangkan tubuh sewaktu mengendarai kerbau agar mengenai saka menjadi hal yang tak mudah untuk dilakukan.Saka adalah tongkat kayu yang ditancapkan di salah satu sudut area sawah, saka ini menjadi tonggak para joki agar dapat menjatuhkan atau mengenai saka dengan waktu secepat mungkin. Pada dasarnya para 
peserta tradisi Barapan Kebo tidak fokus mengincar hadiahnya saja, namun lebih untuk menikmati keseruan berpartisipasi bersama masyarakat lainnya.

Para pemilik kerbau dengan antusias mendatangkan kerbau pilihan mereka yang nantinya akan ditandingkan dengan kerbau lainnya. Tradisi seperti ini biasanya dilakukan sebelum dan sesudah musim panen. Barapan Kebo ini adalah ungkapan syukur masyarakat Sumbawa kepada Sang Pencipta sekaligus menjadi salah satu upaya untuk menggemburkan tanah.

Selain itu, tradisi ini juga menjadi penyambung silaturahmi masyarakat Sumbawa kepada sesama dengan berbagi suka cita. Tradisi Barapan Kebo ini telah menjadi akar budaya masyarakat Sumbawa yang diberlangsungkan di area sawah terpilih.Tiap Kerbau yang akan menjadi peserta dalam tradisi ini dibedakan berdasarkan umurnya. Dimulai dari kelas TK hingga kelas dewasa. Umur kerbau biasanya dari 1 tahun sampai 5 tahun (ketika kerbau telah beranjak dewasa). Dalam hal ini tradisi Barapan Kebo lebih menjadi arena martabat dan pertarungan harga diri bagi para joki. Apalagi harga kerbau akan jadi melonjak apabila berhasil menjadi juara dalam perlombaan Barapan Kebo ini. Bayangkan saja, harga seekor kerbau akan menjadi naik sekitar Rp100 juta. Luar biasa, ya, Sahabat Barapan Kebo adalah salah satu tradisi khas masyarakat Sumbawa yang menjadi ciri khas tradisi Nusantara. Tentunya akan menjadi tanggung jawab bagi para generasi muda agar selalu mencintai budaya sendiri supaya tradisi unik ini tidak akan tergerus oleh zaman.

\section{KESIMPULAN}

Barapan Kebo merupakan suatu tradisi khas yang dimiliki masyarakat agraris di Sumbawa yang hingga kini masih tetap dirawat. Hidupnya ada di keseharian suku yang berjuluk Tau Sabalong Samalewa (Samawa) tersebut. Barapan Kebo adalah salah satu tradisi khas masyarakat Sumbawa yang menjadi ciri khas tradisi Nusantara. Tentunya akan menjadi tanggung jawab bagi para generasi muda agar selalu mencintai budaya sendiri supaya tradisi unik ini tidak akan tergerus oleh zaman.

\section{DAFTAR PUSTAKA}

http://kobarksb.com/?p=5360\#sthash.h8Kp3OZ D.dpbs kebudayaanindonesia.net/kebu dayaan/1311/kepercayaan-dan-tradisisuku-sumbawa

http://fajri-untuksumbawa.blogspot.co.id/ https://id.wikipedia.org/wiki/Suku_Sumbawa http://protomalayans.blogspot.co.id/2012/11/su ku-sumbawa-nusa-tenggara-barat.html Imansyah, Yadi. "The Existence of Traditional Sport (Barapan Kebo) and Character Values of Barapan Kebo in the Society of Sumbawa Regency." Proceedings of The 1st International Conference on Innovative Pedagogy (ICIP) 2017. STKIP Bina Bangsa Getsempena Banda Aceh, 2017.

Rahman

Andi. PENYELENGGARAAN

PEMERINTAH DESA ADAT BERDASARKAN UNDANG-UNDANG NOMOR 32 TAHUN 2004 (Studi di Desa Dalam, Kecamatan Taliwang, Kabupaten Sumbawa Barat). Diss. University of Muhammadiyah Malang, 2007.

Mawarni, Heni, Sarwiji Suwandi, and Slamet Supriyadi. "Local Wisdom in Lawas (Poetry) Ponan Party Ceremony Society of Sumbawa Nusa Tenggara Barat." International Journal of Advanced Engineering, Management and Science 4.2 (2019).

Arfani, Ari. "Konstribusi Nilai-nilai Kearifan Lokal Dalam Membangun Harmoni Sosial Masyarakat Kecamatan Seteluk Kabupaten Sumbawa Barat Pasca Pemilukada Tahun 2010." JURNAL PENDIDIKAN PKN 1.1 (2012). 